\title{
Metaphors of Economy and Economy of Metaphors
}

\author{
Antonio Pamies ${ }^{[0000-0001-8193-9359]}$ and Ismael Ramos Ruiz ${ }^{[0000-0002-5661-0460]}$ \\ ${ }^{1}$ University of Granada, Spain \\ ${ }^{2}$ Palacio de las Columnas. Calle Puentezuelas, $n^{\circ}$ 55, 18071, Granada, Spain \\ apamies@ugr.es
}

\begin{abstract}
The economic discourse is essentially metaphorical, as it is observed in the analysis of its terminology, where economy is generally represented in terms of other domains. The aim of this study is to establish a relation between the metaphors found in economic discourse and the systemic economy of figurative language. A qualitative and quantitative analysis of the most frequent source domains of these constructions has been carried out. The most productive type of metaphor in the discourse on economy is the so-called medical metaphor, where economy is understood as a living organism. We have analyzed a corpus of economic texts from the Spanish press, in order to identify and quantify all the "diseases of the economy", be they terminological, phraseological or purely discursive. We find relevant regularities between the lexicalized metaphors of economic terminology and the internal economy of figurative semantics.
\end{abstract}

Keywords: metaphor, phraseology, Corpus linguistics.

\section{Introduction}

The terminology of economics is basically metaphorical, and -at the same time- economy serves as a model for conceptualizing other domains metaphorically, to the point that even linguistics explains the evolution of languages by means of the so-called principle of linguistic economy [17], which is a dynamic balance between the employed means (syntagmatic and paradigmatic) and the obtained communicative results ${ }^{1}$.

A fundamental resource of this economy is figurative language, which, by structuring one reality in terms of another one, saves having to create and memorize new words, albeit in return for the effort of disambiguate very often. Such analogies are not as arbitrary or unpredictable as they seem, for recurrent associations of ideas have been observed, such as conceptual metaphors ([14]: 43); or culturemes [22], mechanisms considered as very productive (another economic image). This also applies for specialized terminology (cf. [37]). This systematic phenomenon explains why -in the lexicon of modern languages- there is an average of four figurative meanings for each

\footnotetext{
${ }^{1}$ Thus, for example, a language with few phonemes compensates it with polysyllabic words,
} and a language with monosyllabic words compensates it with a rich inventory of phonemes. 
literal meaning, and that one word can accumulate dozens of meanings throughout its history.

\section{Metaphors of economy}

The economy of metaphor may be converted into a metaphor of economy, when this field is the target domain. An outstanding amount of research has been dedicated to the metaphors used in the media when speaking about the banking system or the stock market $([1,2,9,13,21,30,39,40]$, among others). Since, according to Lakoff \& Johnson, metaphor is pervasive in everyday life, not just in language but in thought and action (1980:4-6), its omnipresence in economic discourse also influences individuals' decision making ([4]: 1405). The perception of economic problems is mediated by these omnipresent metaphorical mappings. Stender [36], in a comparative study on Spanish and German with two similar corpora specialized in the recent economic crisis (CrisCorp_DE \& CrisCorp_ES), concludes that HEALTH is the most abundant model (Spanish: 492 tokens; German: 438), followed by WAR (Sp.370; Grm.225), FLUID PHYSICS (Sp.134; Grm.147). Other important source domains are NATURAL CATASTROPHES; MOVEMENT; PRESSURE; BODY PARTS; COLORS; ANIMALS; PLANTS; NAVIGATION; CONSTRUCTION; TRANSPORT; RELIGION; SPORTS; GAMES; etc. The work of Charteris-Black and Ennis [2] about English and Spanish presents a similar ranking of source domains: WAR (English: 67 tokens, 27 types, 23\%) (Spanish 90, 20, 25\%), PHYSICAL HEALTH (Eng. 32 tok., 12 typ., 11\%) (Sp. 32 tok., 7 typ., 9\%), MENTAL HEALTH (Eng. 29 tok.,15 typ., 10\%) (Sp. 78 tok., 26 typ., 22\%); NATURAL DISASTERS (Eng. 49 tok., 12 typ., 17\%) (Sp. 56 tok., 13 typ., 16\%), etc. If we put together physical and mental diseases, the HEALTH model would outnumber WAR.

\subsection{Economic terminology, and its source domains}

Serón's detailed study of collocational metaphors in a corpus of specialized English texts on economy, compared with their Spanish translation by professionals [34], establishes for both languages a list of models, besides the "medical" one. The other iconic models which mainly dominate among the figurative phrasemes are:

ZOOLOGY: condor position; shark watchers; monetary snake; bear market; galloping inflation; vulture fund; swipe fees...

BOTANY: green shoots; to ripe the fruits; economic blossoming; to reap the benefits; the roots of economy; the seeds of development; to harvest millions of dollars; the roots of poverty...

NATURAL CATASTROPHE: economic earthquake; seismic shift; $M \& A$ drought; to flood the market; economic plague; monetary storm...

TRANSPORT: financial highway; to brake consumption; taking its foot off the accelerator; put on the brakes; the train of progress; fuel of economy; to run out of steam; keep the market afloat; buoyant markets; sinking banks; economic taking-off; a hard landing...

MECHANICS: job machine; balance of trade; economy is overheating; to cool the economy; to give a quick start; to grease the wheels; monetary flexibility... 
WAR: to fight inflation; to combat deflation; to beat the index; monetary offensive; to attack the euro; to defeat unemployment; to destroy concurrency; commercial war; to conquer the market; financial strategy; marketing tactics...

Therefore, the models underlying the metaphors in the target domain of economy are the same as those that rule common phraseology in many languages: BODY, AGGRESSION, MOVEMENT, TEMPERATURE, ANIMALS, PLANTS, RELIGION, etc. [27]. A calculation on Slovak Phraseology by P. Đurčo ([7]: 730), based on the 8000 Slovak idioms contained in Soták's dictionary finds out that, whatever their target domain, their most productive source domains are: ANATOMY; METEOROLOGY; PHYSIOLOGY; MATERIAL OBJECTS; ZOOLOGY; ABSTRACT CONCEPTS; FOOD \& PLANTS; RELIGION; PERSONS; CONSTRUCTION; MATERIALS and CLOTHES.

English folk phraseology on economic affairs shows that, for the profane, this field also has abundant verbal images with the same source domains:

as poor as a church mouse; as poor as a dog; to be moth-eaten; to be vermin-eaten; to have only a shirt on one's back; to live from hand to mouth; put your money where your mouth is; to go through hard times; to fall in poverty; to go through hell; to be hard up; money does not grow on trees; to be wealthy; to be affluent; to be loaded; to be rolling in money; to be flush with money; to be on easy street; to be a sugar-daddy; to be filthy rich; to be stinking rich; to be lousy with money...

\subsection{The medical model}

Some types of metaphors are more productive than others, not only in frequency, but also in variety, as in the so-called medical metaphor, which reflects an organic view of the economy (e.g. anemic economy; healthy economy; sick economy; financial cancer; to heal the finances; market ills; chronic shortfall; endemic poverty), and which has been specifically investigated by [21, 30, 38] among others.

In previous studies we have created a Spanish corpus for specific purposes [31, 32, 33], composed of 2333 texts and 2.985.594 words, taken from two important national newspapers (El País and El Mundo) and 70 specialized economic journals (including Expansión, El Economista, Cinco Días, Actualidad económica, elblogsalmon.com, finanzas.com, icnr.com). The compilation included two steps. First, creating a list of potential medical terms (monolexical or multi-lexical) used in the metaphorical constructions on economy, according to the International Classification of Diseases (10th Sp. ed.). Second, the resulting list has been enriched with synonyms, and morphological variants. Once the definitive list is established, each term of the list is introduced into the $M y N e w s^{\circledR 2}$ platform, which allows accessing both printed and digital publications, in order to extract we extract the occurrences of all the medical terms of our economic texts.

\footnotetext{
${ }^{2}$ As its website explains, "MyNews Hemeroteca is the only digital newspaper library of the modern Spanish press and it has become the most used tool in journalistic documentation among information professionals. With MyNews Hemeroteca you will be able to recover the news published in the Spanish press from 1996. It considers more than 190 titles (national, economic, regional, sport and free press)" (http://hemeroteca.mynews.es/about/).
} 
Later, we have applied a simplified version of the Metaphor Identification Procedure (MIP) designed by the Pragglejaz group [5] in order to establish, for each lexical unit in a stretch of discourse, whether its use can be described as metaphorical in this particular context. This simplified system entails a selection process instead of an annotation procedure, beginning with the reading of the recovered text, in order to assure that its content really belongs to the economic field, as well as verifying the presence of (at least) the searched term and the existence of a literal medical meaning of this given term. Within the "medical" metaphor, we have found different subcategories, depending on the kind of disease recalled by the source sub-domain. The following graphic shows their distribution.
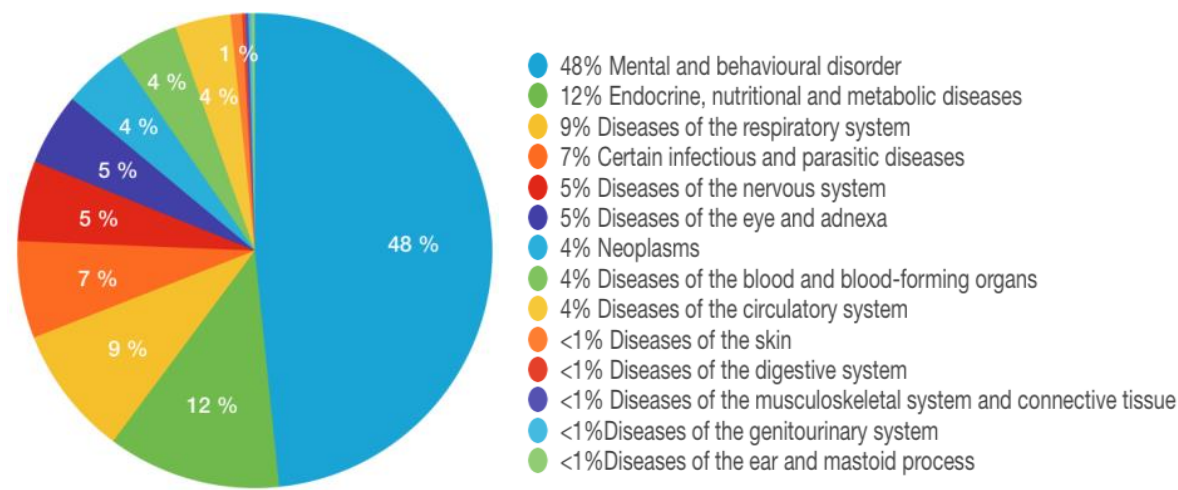

Fig. 1. Sector graph of the average of each disease in the corpus of texts.

To make the study achievable, we limit here to ten the number of recovered texts selected for each term, so we discard a high number of repeated tokens, but we keep all the types, even if they appear only once. Surprisingly, this test finds out that mental and behavioral disorders represent the great majority (48\%) of the medical Spanish metaphors of economic discourse. But, of course, these numbers are representative of the variety of each model (types), not of its frequency (tokens). On the other hand, this calculation can include only specific medical terms, not general concepts such as ill, disease, heal, health, etc. which could not be classified in such a distribution.

\section{Formal economy and semantic economy}

3.1. Most of the involved examples are phraseologisms, whether they be collocations (galloping inflation), idioms (to run out of steam), phraseo-terms (condor position), onymic constructions (International Monetary Fund) or even proverbs (don't sell the bear's skin until you hunt it). From a formal point of view, all of them are characterized by their fixedness, a property which is not limited to the grammatical constraints between the components (e.g. financial net neither allows $<*$ this net is financial $>$ nor $<*$ how financial is that web>). Fixedness has also been defined in terms of frequency (co-occurrence of lexical items higher than randomly expected). This brings us back to the linguistic economy, since frequency is a purely quantitative fact, used as a de- 
fining feature of phrasemes. What Firth called collocation [in the broad sense] was exclusively limited to this criterion: words in habitual company ([8]: 14). Two factors should measure this mutual expectancy. For Sinclair \& Jones [35], the global frequency of co-occurrence is compared to that of the components separately; whereas Halliday ([11]: 276) compares it to the normal probability of co-occurrence ${ }^{3}$. Hence, subsequent algorithms have been proposed and investigated for the automatic detection of phrasemes on a statistical basis in large electronic corpora (e.g., [6, 12, 29, 4]), taking for granted that a phraseologism is defined as the co-occurrence of a form or a lemma of a lexical item and one or more additional linguistic elements of various kinds which functions as one semantic unit in a clause or sentence and whose frequency of co-occurrence is larger than expected on the basis of chance ([10]: 3).

However, the difficulties encountered in the automated detection experiments come to question the principle of co-occurrence frequency of the components, because the global frequency of some idioms is very low [4], or because the individual frequency of some components is very high, for ontological reasons. Mathematically, the number of combinations of several items is potentially higher than the number of items, although this theoretical possibility is not necessarily actualized. For example, Đurčo ([7]: 730) calculates that the 8000 Slovak idioms included in Sotáks's dictionary comprise 17600 words, with an average of 2,26 "full words" per phraseme, and, although some components are highly recurrent, their average repetition is only 3,40 . Besides, in speech, the individual frequency of a word depends on the ontological properties of its referent. Relative frequency is often useful for automatic processing purposes [3], but it is not a reliable criterion in order to define phrasemes from a theoretical point of view.

Therefore, from the point of view of linguistic economy, it is not the formal frequency itself that characterizes phraseologisms, but the multiplier effect of their combinatory nature, both in form and content. Following Martinet's reasoning [17], if natural languages may designate an infinite number of referents, it is thanks to their double articulation: a small number of meaningless units (phonemes) serves to form thousands of meaningful major units (lexemes). This is why Mejri, defines the phraseological level as the third articulation of language [18, 19, 20], which consists of combining lexemes within the language system, assigning to the members of this paradigm a global meaning that differs from the one they would have if joined syntagmatically, as they are in free speech (e.g. to pull one's leg $)^{4}$. Polysemy and idiomaticity are two faces of the same coin, their economy does not only reduce the formal paradigms level but also the number of "directly accessed" meanings.

${ }^{3}$ collocation is the syntagmatic association of lexical items, quantifiable, textually, as the probability that there will occur at $\mathbf{n}$ removes (a distance of $\mathbf{n}$ lexical items) from an item $\mathbf{x}$, the items a, b, c... ([11]: 276).

${ }^{4}$ For this purpose, Mejri inverts the order of Martinet's articulations: the meaningless (phonemic) level would be the first one, instead of the second. 


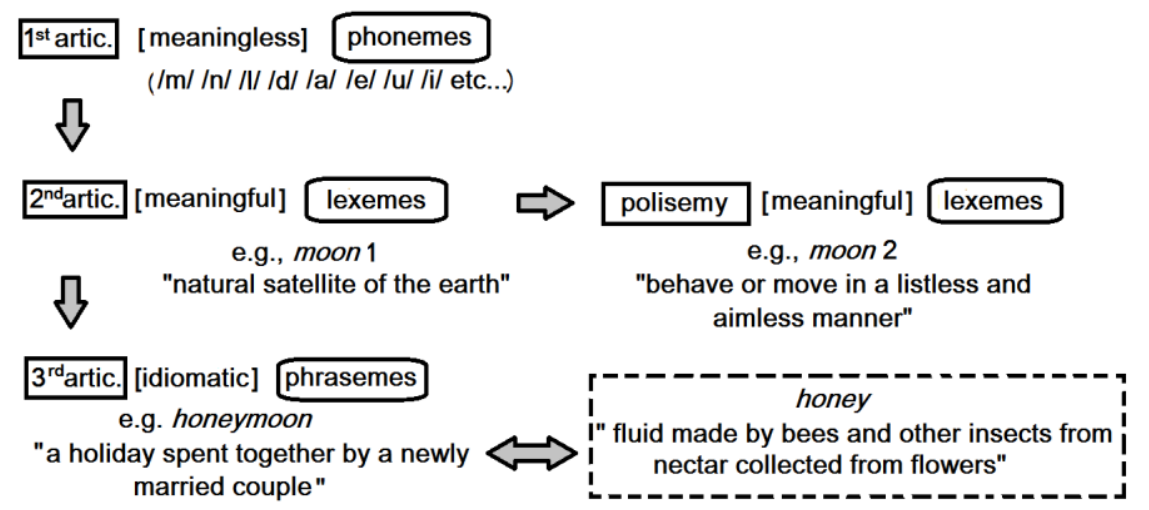

Fig. 2. Our interpretation of Mejri's troisème articulation in relation with polysemy.

3.2. Among the mental models underlying metaphors based on other target domains, the notional field of ECONOMY stood out -as a source domain- for long before linguists discovered the principle of linguistic economy. Natural languages took notions from economy to represent other concepts, which objectively little have to do with it. Thus, concepts such as POSSESSING, GIVING, LOSING, SELLING, BUYING, STEALING, INHERITING, etc., conceptualize the most diverse actions as if they really dealt with ownable and transferable goods (to have sorrows, to pay attention, to lose one's nerves, sold out to the enemy, to steal one's heart, a bought off judge, etc.). However, except as a humorous resource, we do not say <*he lost his nerves and the keys of his car >; <*he has many sorrows and a big house >; <*she stole my heart and my motorcycle〉, <*they bought the referee and a new stadium>, because the semantic difference between meanings affects the syntactic behavior of these verbs. POSSESSION, DONATION, LOSS, RETURN, PURCHASE, etc., behave as what Lakoff calls Idealized Cognitive Models ([16]: 6), conceptualizing the maximum information with a minimum cost, thanks to the fact that information that is previously structured allows an easier access to the one that is not. Natural languages have even grammaticalized certain tools specialized in marking possession relationships, such as genitives, datives, or possessive pronouns. However, by means of grammatical metaphors [25], the function of these morphological markers has been also extended to express other relationships, which -in the "real world"- are neither possessive nor dative: my faculty, my neighbors (cf. [23, 24, 28]. This bi-directionality between source and target domains is also an essential factor for linguistic economy since it duplicates the productivity of figurative language.

\section{Discursive economy and linguistic economy}

The economy of metaphor is not limited to phraseologisms (those that are already lexicalized), it also affects free speech. Even in the domain of economics, "creative" metaphors of the speakers are usually understood by the receivers of the message, despite their novelty. E.g. DEATH metaphor, or NATURAL CATASTROPHE metaphor, 
magnifying a loss frame, ([40]: 1408), share the same metaphoric macro-models as the figurative lexicalized phrasemes already mentioned. For example, sequences such as:

- a devastating deflation set in... -after savaging the financial markets... -deflation is a bigger threat [1].

-both private and institutional investors are still trying to recover from the wounds that the equity crash inflicted on their portfolios...

-higher productivity is the only way that Japan can defeat the twin demons of aging and fiscal deficits...

-there are signs that even moribund retail sales could find themselves resuscitated [34].

-In China, surplus capacity and sliding prices are sounding the death knell for half of the companies making light emitting diode (LED) chips...

-We now inhabit a world of the living dead: a eurozone that will not collapse but cannot be reformed [40].

neither contain idioms nor collocations, but they exploit in free discourse a model which rules idiomatic units, connecting the conceptual domain of aggression with economy. As a consequence of institutionalization, fixedness distinguishes a metaphoric phraseme from a novel metaphor, but it does not prevent the latter from being decoded according to the same semantic model than the former. The most evident variant are the de-automatized idioms, phrasemes that, although being manipulated by the speaker (in form and meaning), are understood by analogy with their model. For example, familias con la deuda al cuello (*families with the debt at the neck = "families with a high debt") ([39]: 303) is decoded by analogy with the idiomatic marine metaphor con el agua al cuello ("with the water at the neck = "up to one's neck"). This derivative mechanism -from more general iconic models to particular metaphorsis another fundamental pillar of linguistic economy.

We may conclude that there is a kind of qualitative and quantitative analogy and feedback between the systemic logic of linguistic economy (e.g. polysemy, third articulation) and the use of metaphors in economy, whose most productive models are systematically reused in figurative expressions mapped onto other target domains. At the same time, economy is the source domain of hundreds of metaphors where economic concepts (POSESSION, DONATION, TRADE, THEFT, etc.) are conceptualizing the most diverse domains (FEELINGS, EMOTIONS, etc.). This bi-directionality of conceptual mappings is also a highly economic resource.

\section{References}

1. Cesiri, D. \& Colaci, L.: Metaphors on the global crisis in economic discourse: A corpus-based comparison of The Economist, Der Spiegel and Il Sole 24 Ore. Rassegna Italiana di Linguistica Applicata 1(2), 201-224 (2011).

2. Charteris-Black, J., Ennis, T.: A comparative study of metaphor in English and Spanish financial reporting. English for Specific Purposes Journal 20(3), 249266 (2001). 
3. Colson, J.: Set phrases around globalization: an experiment in corpus-based computational phraseology. In: Alonso, F., Ortega, I., Quintana, E., Sanchez, M. E. (eds.) Input a Word, Analyze the World. Selected Approaches to Corpus Linguistics. Newcastle upon Tyne: Cambridge Scholars Publishing, pp. 141152 (2016).

4. Colson, J.: Where does phraseology actually begin? Yearbook of Phraseology 6, 1-2 (2015).

5. Crisp, P., Gibbs R., Deignan, A., et al.: MIP: A method for identifying metaphorically used words in discourse. Metaphor and Symbol 22 (2007).

6. Daille, B.: Combined Approach for Terminology Extraction: lexical statistics and linguistic filtering. UCREL, 5 (Univ. of Lancaster), apud. Adam Kilgarriff (1995).

7. Đurčo, P.: Slovak Phraseology. In: Burger, H., Dobrovol'skij, D., Kühn, P., Norrick, N. (eds.) Phraseologie: Ein internationales Handbuch der zeitgenössischen Forschung. Berlin/New York: De Gruyter: vol. 2, pp. 728-736 (2007).

8. Firth, J. R.: Papers in Linguistics 1934-1951. London: Oxford University Press (1957).

9. Gallego Hernández, D.: Estudio comparativo trilingüe de la traducción de la metáfora náutica en el lenguaje económico-financiero. In: Mejri, S., Mogorrón Huerta, P. (eds.) Opacité, idiomaticité, traduction. Alicante: Universidad de Alicante, pp.99-128 (2010).

10. Gries, S.: Phraseology and linguistic theory: a brief survey. In: Granger, S., Meunier, F. (eds.) Phraseology: An interdisciplinary perspective. Amsterdam: John Benjamin, pp. 3-25 (2008).

11. Halliday, M.: Categories of the theory of grammar. Word, 17/3, 241-292 (1961).

12. Heid, U.: Computational linguistic aspects of phraseology. In: Burger, H., Dobrovol'skij, D., Kühn, P., Norrick, N.R. (eds.) Phraseologie/Phraseology. Ein internationales Handbuch der zeitgenössischen Forschung/An International Handbook of Contemporary Research. Berlin/ New York: Walter de Gruyter, pp. 1036-1044 (2007).

13. Kelly, P. F.: Metaphors of meltdown: political representations of economic space in the Asian financial crisis. Society and Space 19 (6), 719-742 (2001).

14. Lakoff, G., Johnson, M.: Metaphors We Live By. Chicago: University of Chicago Press (1980).

15. Lakoff, G.: The contemporary theory of metaphor. In: Ortony, A. (ed.) Metaphor and thought, Second edition. Cambridge: Cambridge University Press, pp. 202-251 (1993).

16. Lakoff, G.: Women, Fire and Dangerous Things: What Categories Reveal about Thought. Chicago: University of Chicago (1987).

17. Martinet, J.: Éléments de linguistique générale. Paris: Armand Colin (1960 [reprint 1980]).

18. Mejri, S.: Délimitation des unités phraséologiques. In Ortiz A. M. L., Huelva Unternbäumen, E. (eds.) Uma [re]visão da teoria e da pesquisa fraseológica. Campinas, Pontes, pp. 139-156 (2012). 
19. Mejri, S.: La mémoire des séquences figées: une troisième articulation, ou la réhabilitation du culturel dans le linguistique?. In: Cinquièmes journées scientifiques du réseau LTT (AUPELF-UREF), Tunis, CERES, pp. 3-11 (1998).

20. Mejri, S.: Polylexicalité, monolexicalité et double articulation. Cahiers de lexicologie 2, 209-221 (2006).

21. O'Mara-Shimek, M.: Metaphor and digital finance reporting of the stock market crash of 2008: Organicist vs. mechanicist visions. Tesis Doctoral, Universidad Católica de Valencia (2011).

22. Pamies A.: The concept of cultureme from a lexicographical point of view. Open Linguistics 3/1 (january), 100-114 (2017).

23. Pamies, A., Natale, D.: Observaciones contrastivas sobre las construcciones posesivas y pseudoposesivas en español e italiano. Beoiberística - Revista de Estudios Ibéricos, Latinoamericanos y Comparativos, 1/1, 11-25 (2017).

24. Pamies, A.: Il concetto di dono nel linguaggio. Conferenza internazionale Da lontano: Dono, Istituzioni e Ospitalità. Napoli, Italia, 27-29 aprile 2016 (in press) (2016a).

25. Pamies, A.: Metafora grammaticale e metafora lessicale: implicazioni teoriche per la fraseologia. In: Dal Maso, E., Navarro, C. (ed.) Gutta cavat lapidem. Indagini fraseologiche e paremiologiche, Mantova: Universitas Studiorum, pp. 87-120 (2016b).

26. Pamies, A.: De la idiomaticidad y sus paradojas. In: Conde Tarrío, G. (ed.) Nouveaux apports à l'étude des expressions figées, Cortil-Wodon (Belgique): Inter-Communications \& E.M.E., pp. 173-204 (2007).

27. Pamies, A.: Modelos icónicos y archimetáforas: algunos problemas metalingüísticos en el ámbito de la fraseología. Language Design, 4, 9-20 (2002b).

28. Pamies, A.: Sémantique grammaticale de la possession dans les langues d'Europe. In: Castagne, E. (ed.) Modélisation de l'apprentissage simultané de plusieurs langues apparentées, Nice: Université Sophia-Antipolis: 67-98 (2002a).

29. Pazos, J. M., Pamies, A.: Combined statistical and grammatical criteria for the retrieval of phraseological units in an electronic corpus. In: Granger S., Meunier. F. (eds.) Phraseology: an Interdisciplinary Perspective. Amsterdam: John Benjamins, pp. 391-406 (2008).

30. Peckham, R.: Economies of contagion: financial crisis and pandemic. Economic and Society, 42 (2), 226-248 (2013).

31. Ramos Ruiz, I.: El cáncer de la economía: La fraseología de las metáforas médicas periodísticas. Opción, 31(76), 747-767 (2015).

32. Ramos Ruiz, I.: La metáfora en el periodismo económico: infecciones económicas. In: Mendieta, A., Santos, C.J. (eds.) Líneas emergentes en la investigación de vanguardia. Madrid: McGraw-Hill Interamericana, pp. 515524 (2014).

33. Ramos Ruiz, I.: La metáfora médica como dominio fuente en los spots electorales de contenido económico. In: Padilla, G. (ed.) Estrategias en comunicación y su evolución en los discursos. Madrid: McGraw-Hill Interamericana (2016).

34. Serón Ordóñez, I.: La traducción de la metáfora en los textos financieros: estudio de caso. In: Torres, M. G. (ed.) Traducción y cultura: el referente 
cultural en la comunicación especializada, Málaga: ENCASA, pp. 205-250 (2005).

35. Sinclair, J. M., Jones, S.: English lexical collocations: A study in computational linguistics. Cahiers de Lexicologie, 24(2), 15-61 (1974).

36. Stender, A.: El lenguaje económico alemán y español de la prensa especializada: análisis basado en un corpus de la crisis económica (CRISCORP). Tesis doctoral. Sevilla: Universidad Pablo de Olavide (2015).

37. Tercedor, M.: Rutas de metaforización y traducción especializada: una aproximación cognitiva. Sendebar, 10/11, 249-260 (2000).

38. Vukićević-Đorđević, L.: On Biological Metaphors in Economic Discourse. Journal of Teaching English for Specific and Academic Purposes, 2(3), 429443 (2014).

39. White, M.: Metaphor and economics: the case of growth. English for Specific Purposes, 22, 131-151 (2003).

40. Williams, A. E.: Metaphor, Media, and the Market. International Journal of Communication, 7, 1404-1417 (2013). 